\title{
Dynamics of changes in colorectal cancer incidence in the Podkarpackie region (Poland) in the years 1963-2014
}

\author{
Jan Gawełko', Grażyna Hejda², Igor Radziewicz-Winnicki ${ }^{1}$, Paulina Hejda², Katarzyna Dereñ \\ ${ }^{1}$ Institute of Medical Sciences, Medical College of Rzeszow University, Rzeszow, Poland \\ ${ }^{2}$ Institute of Health Sciences, Medical College of Rzeszow University, Rzeszow, Poland
}

Gastroenterology Rev 2021; 16 (2): 117-126

DOI: https://doi.org/10.5114/pg.2021.106662

Key words: colorectal cancer, incidence, epidemiology.

Address for correspondence: Katarzyna Dereń PhD, Institute of Health Sciences, Medical College of Rzeszow University, Rzeszow, Poland, phone: +48 17872 1153, e-mail: kderen@ur.edu.pl

\begin{abstract}
Introduction: Colorectal cancer (CRC) in Podkarpackie in Poland is the third most common cancer in males $(12.6 \%$ cancer diagnoses), and second among women (10.1\% of recognised cancers).

Aim: An analysis of the trends in CRC incidence in the years 1963-2014 in Podkarpackie in the south-east of Poland.

Material and methods: A total of 19,460 CRC cases recorded in the period 1963-2014 in the National Cancer Registry as ICD C18-C21 cases were analysed.

Results: The overall cancer incidence rate in Podkarpackie Province was 20.4 in men and 16.8 in women per 100 thousand, and was lower than the Polish population by $12.4 \%$ for men and by $17.6 \%$ for women, respectively, in comparison to general Polish population rates. The mean age of CRC diagnosis grew from 64.0 years in males and 64.5 years in females in 1963-1969 to 67.6 and 68.4 years in 2010-2014, respectively.

Conclusions: In 1964-2014 the CRC incidence rate in the Podkarpackie region increased 12.7-fold in males and 8.1-fold in females. There was an observed stable growth of average annual increase in the CRC incidence rate in men in 1963-1999, but since 2000 a decline in this rate has been observed. In females there was a tendency towards increased average CRC incidence rate in Podkarpackie since 2000, while in the whole country the female population presented a stable decrease of this coefficient.
\end{abstract}

\section{Introduction}

Colorectal cancer (CRC) is one of the world's most common malignant neoplasms. Over one million new cases of colorectal cancer are diagnosed each year globally, and more than 600,000 patients die each year. The highest rates of incidence are observed in Europe, North America, and Oceania, whereas the lowest are observed in West Africa. About 2/3 of colorectal cancer cases occur in highly developed countries. Over the next 15 years, the number of new cases is expected to rise to 2.2 million and the number of deaths 1.1 million [1-3]. It is worth noting that there is in Poland a statutory obligation to report patients with suspected or diagnosed cancer to the National Cancer Registry. The information is collected in a centralized database. Based on this, reports and analyses are created to assess the cancer incidence and prevalence in the country, determining the needs of oncological treatment and assessing the effectiveness of cancer diagnosis and treatment.

The reporting system includes 16 local registration offices (registers), which collect data and enter them into the common database of the National Register. During data collection basic data validations are carried out based on dictionaries and validation rules implemented in the system. The local offices publish detailed reports for voivodships (country regions).

The completeness of the Registry in the early 1960s was around $70 \%$ and to rose to $95 \%$ in 1996 . Due to the protests of healthcare workers in 1997-1998 data collection was incomplete; there are no data for this period for both Poland and the Podkarpackie region. This situation was overlapped with the introduction of the ICD-10, which resulted in an increase in the percentage 
of C80 diagnostic code (malignant neoplasm without specification of site) and problems with the correct coding in some colorectal cancer registries. These difficulties are still visible in the shortages of completeness in registry case collection, which significantly reduces the quality of acquired data, especially assessment of the tumour location, the clinical stage, and histopathological assessment.

Particularly significant problems occur in the analysis of deaths obtained from censuses, in which the ICD 10 coding is limited only to the main organ code or C76, C80, 97 NOS ("garbage codes"), which in turn results in the possibility of epidemiological bias. In 2013, 29.5\% of death records were improperly coded in ICD 10 classification, which affected real cause of death identification $[4,5]$.

In this situation, it is crucial to obtain complete data on the incidence of colorectal cancer in Poland. This can be achieved only with colon cancer screening tests. In the national colon cancer screening program launched in October 2000, colonoscopy was used as a basic screening tool to allow detection and histopathological and clinical verification of precancerous and neoplastic conditions [6-8].

Colorectal cancer is currently one of the most frequently observed malignant neoplasms in Poland. As regards disease distribution, it was ranked third (12.6\%) in men in 2014 and second (10.1\%) in women in the region. A similar distribution was observed in the Podkarpackie region. Colorectal cancer in men was ranked third (10.9\%) after prostate cancer and lung cancer, and second in women (9.4\%) after breast cancer (18\%) [9].

\section{Aim}

The purpose of this work is to assess the dynamics of colorectal cancer incidence in the years 1963-2014 in the Podkarpackie region, taking into account changes in the country's administrative division. The incidence proportion in women and men, crude and standardised rates of incidence, the average rate of increase in the disease incidence, and the patients' age have been assessed; all these data refer to the data for Poland.

\section{Material and methods}

A retrospective analysis of 19,460 colorectum cancer (C18-21) cases in 1963-2014 in the Podkarpackie region (Poland) was performed in the area covering the following regions/periods: from 1963 to 1974, the area of the former Rzeszowskie Voivodeship, in 1975-1998 the area of the former Krośnieńskie, Przemyskie, Rzeszowskie, and Tarnobrzeskie Voivodeships, and from 1999 from the area of the Podkarpackie Voivodeship.
Historical data on the disease incidence in the region of today's Podkarpackie Voivodeship comes from a number of public cancer registers and reports from the Voivodeship consultants in oncology specific to the Podkarpackie area, collected over the period under review by the relevant administrative bodies responsible for analysing the state of health of the inhabitants of the region.

The data for Poland were obtained from the publication of the Oncology Centre and the National Cancer Register in Warsaw.

Demographic data for the period considered were obtained from the Voivodeship Statistical Office in Rzeszow. Based on the generally known statistical procedures, the crude rates, the standardised rates, the average annual rate of increase of the disease incidence, and the average age at cancer diagnosis in men and women between 1963 and 2014 were calculated. Due to the protests of the health professionals in 1997-1998 (i.a. completing medical documentation was abandoned), data for Poland and the Podkarpackie region are missing for this period.

\section{Results}

Between 1963 and 2014 the number of cases of colorectal cancer (C18-C21) in the Podkarpackie region rose from 41 to 520 in men and from 54 to 438 in women. The number of cases identified in Poland also increased in the same ratio (more than 12-fold for men and more than 8-fold for women). The number of 100 cases for the Podkarpackie region per year was exceeded in 1978 for men and in 1980 for women, and the number of 300 cases in 2000 and 2004, respectively.

The average incidence rate of malignant neoplasms in the 1963-2014 period in the Podkarpackie region, among both men and women, was lower than the average rate for Poland. In the case of men, the crude rate in the Podkarpackie region was 20.4 per 100 inhabitants and $12.4 \%$ less than the national level, while for women it reached a value of 16.8 , i.e. $17.6 \%$ less than in the whole country. However, the average annual rate of increase of these rates over the period considered in both cases was close to the same level (4.6\% for men and $3.7 \%$ for women) (Table I, Figures 1, 2).

Given the wide range of the period under consideration (51 years), it was further subdivided into sub-periods corresponding to 10 years, starting with a rounded year, i.e. the 1960s, 1970s, etc., while the first one covers the period 1963-1969 (7 years) and the last sub-period covers the years 2010-2014 (5 years) due to the start of the observation in 1963 and its completion in 2014. 
Table I. Colorectal cancer (C18-C21) incidence in the years 1963-2014

\begin{tabular}{lcccc}
\hline \multirow{2}{*}{ Sex } & Region & \multicolumn{3}{c}{ Crude rate } \\
\cline { 3 - 5 } & & Arithmetic average & Standard deviation & $\begin{array}{c}\text { Annual average rate } \\
\text { of increase }\end{array}$ \\
\hline \multirow{2}{*}{ Men } & Podkarpackie region & 20.4 & 14.3 & $4.6 \%$ \\
\cline { 2 - 5 } & Poland & 23.3 & 14.5 & $4.6 \%$ \\
\hline \multirow{2}{*}{ Women } & Podkarpackie region & 16.8 & 9.8 & $3.7 \%$ \\
\cline { 2 - 5 } & Poland & 20.4 & 10.2 & $3.8 \%$
\end{tabular}

A

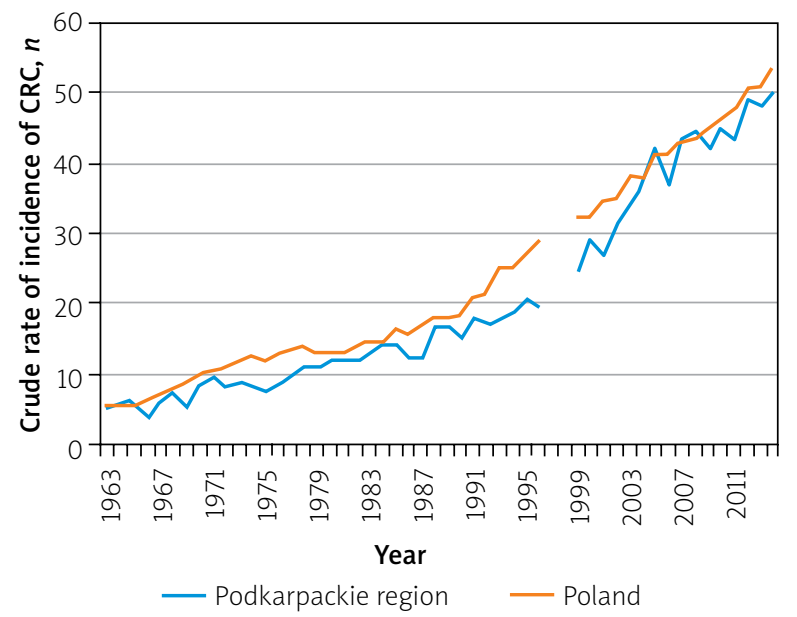

B

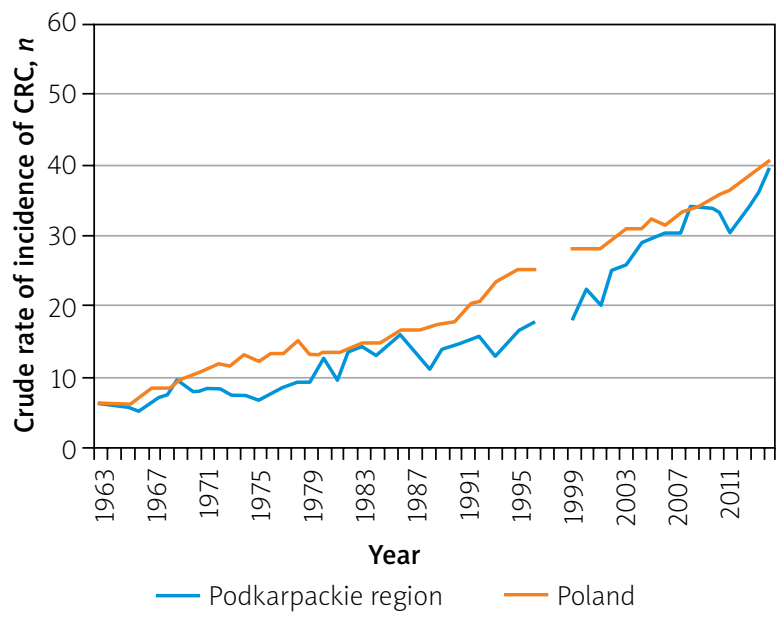

Figure 1. Crude rate of incidence of colorectal cancer (C18-C21) in the years 1963-2014: A - men, B-women

A

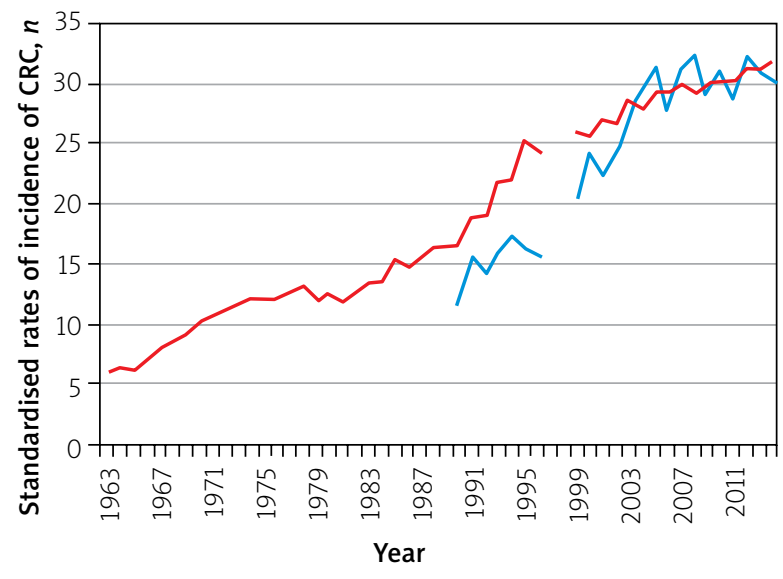

- Podkarpackie region Poland
B

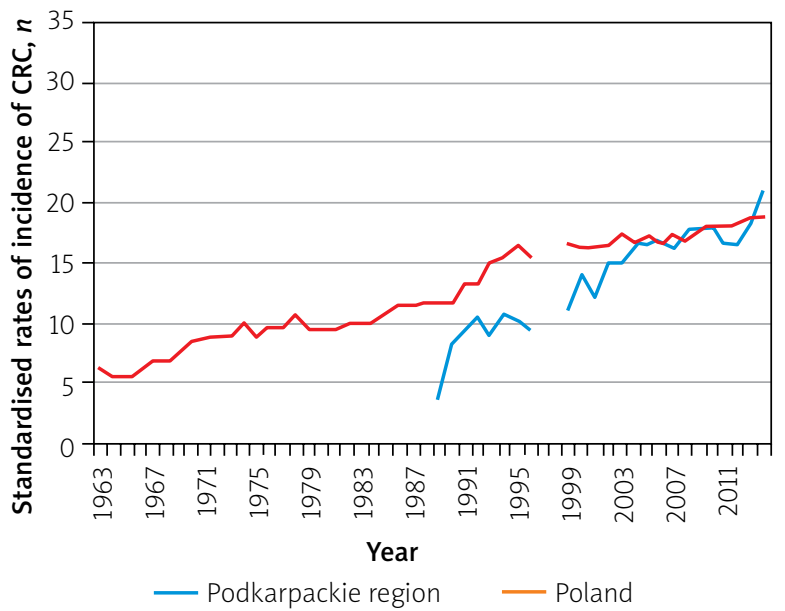

Figure 2. Standardised rates of incidence of colorectal cancer (C18-C21) in the years 1963-2014: A - men,

\section{B -women}

The average value of the crude male incidence rate for colorectal cancer (C18-C21) in the 1960s in the Podkarpackie region was 5.5 per 100,000 inhabitants and 6.8 in the whole of Poland. In each subsequent decade, both in the Podkarpackie region and in the whole country, it grew steadily, reaching in the second decade of the $21^{\text {st }}$ century the values of 47.1 and 49.9 , respectively (Table II, Figure 3). From the 1960s up to the $1990 \mathrm{~s}$ the average annual rate of increase for the Podkarpackie region increased over each decade (from $0.6 \%$ to $5.7 \%)$. This process slowed down in the early 2000 s. This resulted in a decrease in the rate of increase in 
Table II. Colorectal cancer (C18-C21) incidence in the years 1963-2014 per decade

\begin{tabular}{|c|c|c|c|c|c|c|c|}
\hline \multirow[t]{3}{*}{ Sex } & \multirow[t]{3}{*}{ Years } & \multicolumn{6}{|c|}{ Crude rate } \\
\hline & & \multicolumn{2}{|c|}{ Arithmetic average } & \multicolumn{2}{|c|}{ Standard deviation } & \multicolumn{2}{|c|}{ Annual average rate of increase } \\
\hline & & Podkarpackie region & Poland & Podkarpackie region & Poland & Podkarpackie region & Poland \\
\hline \multirow[t]{6}{*}{ Men } & 1963-1969 & 5.5 & 6.8 & 1.1 & 1.4 & $0.6 \%$ & $8.5 \%$ \\
\hline & 1970-1979 & 9.2 & 12.1 & 1.2 & 1.3 & $2.7 \%$ & $2.9 \%$ \\
\hline & 1980-1989 & 13.5 & 15.4 & 1.9 & 1.9 & $3.8 \%$ & $3.6 \%$ \\
\hline & 1990-1999 & 18.9 & 25.0 & 2.9 & 4.6 & $5.7 \%$ & $6.4 \%$ \\
\hline & 2000-2009 & 36.8 & 39.4 & 6.3 & 4.3 & $5.1 \%$ & $3.0 \%$ \\
\hline & 2010-2014 & 47.1 & 49.9 & 2.8 & 2.8 & $4.6 \%$ & $4.0 \%$ \\
\hline \multirow[t]{6}{*}{ Women } & 1963-1969 & 6.7 & 7.3 & 1.6 & 1.3 & $7.8 \%$ & $7.3 \%$ \\
\hline & 1970-1979 & 8.1 & 12.5 & 0.8 & 1.4 & $1.4 \%$ & $2.6 \%$ \\
\hline & 1980-1989 & 13.2 & 15.4 & 1.7 & 1.6 & $1.3 \%$ & $3.1 \%$ \\
\hline & 1990-1999 & 15.8 & 23.2 & 1.7 & 3.4 & $2.8 \%$ & $5.2 \%$ \\
\hline & 2000-2009 & 28.1 & 31.4 & 4.7 & 2.3 & $6.0 \%$ & $2.3 \%$ \\
\hline & 2010-2014 & 34.5 & 38.1 & 3.3 & 2.1 & $8.6 \%$ & $3.7 \%$ \\
\hline
\end{tabular}

A

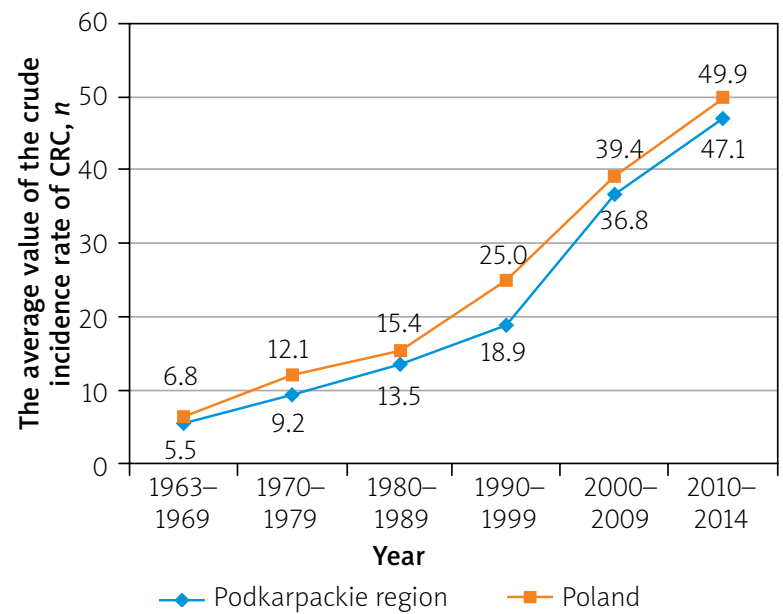

B

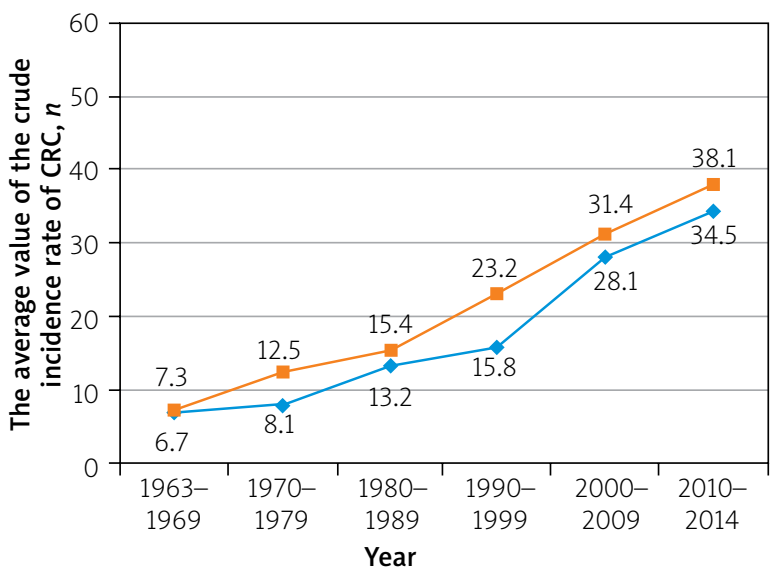

Figure 3. The average value of the crude incidence rate of colorectal cancer (C18-C21) in particular decades of the 1963-2014 period: A - men, B - women

the first decade to $5.1 \%$, and in the following decade to $4.6 \%$. In Poland, the largest average annual rate of increase in the male incidence rate was observed in the 1960 s $(8.5 \%)$, while in the following decades it remained close to the regional level (Table II, Figure 4).

Among women, the average value of the crude incidence rate of colorectal cancer (C18-C21) at the beginning of the analysed period was 6.7 per 100,000 inhabitants for the Podkarpackie region, while in Poland it was 7.3 , and in both cases it was higher than that of men. This dependence continued over the next 2 decades. In the 1990s the trend reversed; the rates for men started to exceed the rates for women. This trend continued until the end of the observation period. Moreover, both in the Podkarpackie region and in the whole country, in the next decade the incidence rate in women increased (similarly to that in men), and it reached values of 34.5 and 38.1 in 2010-2014, respectively (Table II, Figure 3). From the 1960s to the 1990s, the average annual rate of increase in disease incidence in women in the 2 areas concerned was characterised by a similar pattern of volatility. Starting form a high level (above $7 \%$ in the first decade) the rates declined significantly over the next 3 sub-periods (with the national pace being about twice as high as the regional one in both areas). The beginning of the $21^{\text {st }}$ century, with the continued national pace of rate of increase, resulted in a significant growth in the average annual rate of increase in women in the 
A

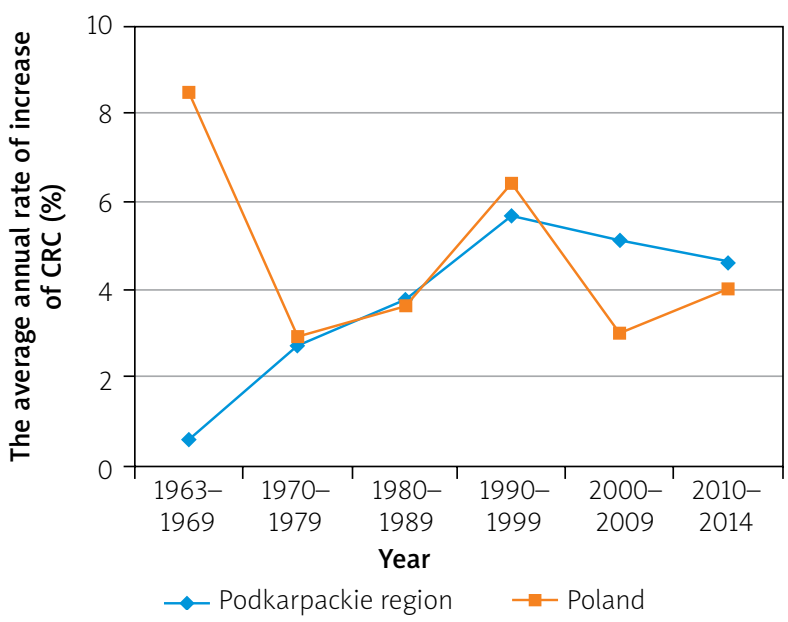

B

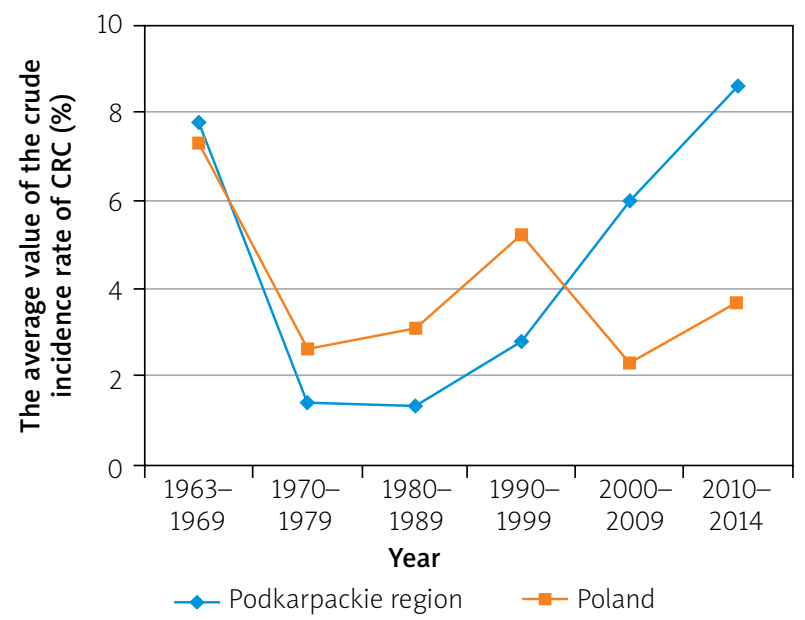

Figure 4. The average annual rate of increase of colorectal cancer (C18-C21) in particular decades of the 1963--2014 period: A - men, B - women

Podkarpackie region (contrary to the trend before, the regional rate was around twice as high as the national rate during this period) (Table II, Figure 4).

Based on the evidence available, the average age of colorectal cancer patients was calculated and showed a moderate upward trend over the period considered (Table III). An analysis of the disease incidence in patients under and over 50 years of age was also carried out. In view of the changes in the subsequent ICD revisions, the clear separation between the various Colorectum neoplasms in the material available for analysis was possible based on the Tenth Revision, hence separate plots for the values $\mathrm{C} 18, \mathrm{C} 19, \mathrm{C} 20$, and C21 have been presented for data since the 1990s (Figures 5, 6).

\section{Discussion}

Colorectal cancer is a malignant neoplasm of the colon, the rectosigmoid junction, the rectum, the anus, and the anal canal (C18-C21).

In 2014 in Poland colorectal cancer was the third most common group of malignant neoplasms diagnosed in male patients, after lung cancer and prostate cancer, and the second most common group of malignant neoplasms diagnosed in female patients, following breast cancer. This group of neoplasms (C18-C21) is far from homogeneous. Thus, colon cancer was ranked $4^{\text {th }}$ in male patients (6.8\% of all malignant tumours) and $5^{\text {th }}$ in female patients $(6.2 \%)$, while rectum cancer was ranked $6^{\text {th }}(4.6 \%)$ and 9 th $(2.9 \%)$, respectively. Cancers of the rectosigmoid junction and of the rectum were ranked even lower [9]. In Poland, in the years 19992014 there were 230,877 registered cases of colorectal cancer; among them, $56.6 \%$ were colon cancers (C18), $5.4 \%$ rectosigmoid junction cancers (C19), 35.5\% can-
Table III. Average age of patients

\begin{tabular}{lcc} 
Years & \multicolumn{2}{c}{ Sex } \\
\cline { 2 - 3 } & Men & Women \\
\hline $1963-1969$ & 64.0 & 64.5 \\
\hline $1970-1979$ & 62.9 & 65.1 \\
\hline $1980-1989$ & 64.1 & 65.2 \\
\hline $1990-1999$ & 65.1 & 67.6 \\
\hline $2000-2009$ & 67.3 & 69.2 \\
\hline $2010-2014$ & 67.6 & 68.4
\end{tabular}

cers of the rectum (C20), and $2.5 \%$ cancer of the anus (C21).

In the same period in Podkarpackie, out of 11,635 cases of diagnosed colorectal cancers (C18-C21) 51.6\% were colon cancers (C18), $7.2 \%$ were rectosigmoid junction cancers (C19), 38.7\% rectal cancers (C20), and $2.5 \%$ anus cancers (C21) [9-44].

In the Czech Republic, in 1999-2014, out of 129,226 cases of colorectal cancer, $51.6 \%$ were colon cancers (C18), 13.1\% rectosigmoid junction cancers (C19), $27.7 \%$ cancers of the rectum (C20), and $1.4 \%$ cancers of the anus (C21). In the study published by Rafiemanesh et al. in 2003-2008, out of 25,704 colorectal cancers, $61.83 \%$ were cancers of the colon, $27.54 \%$ cancers of the rectum, $7.46 \%$ cancers of the rectosigmoid junction, and $3.1 \%$ cancers of the anus $[45,46]$.

Over the period of 50 years, a rapid growth in colorectal cancer incidence has been observed. The dynamics of changes in this area is shown by the fact that between 1963 and 2014, the number of colorectal cancer cases rose from 41 to 520 among men and from 54 to 438 among women. 
A

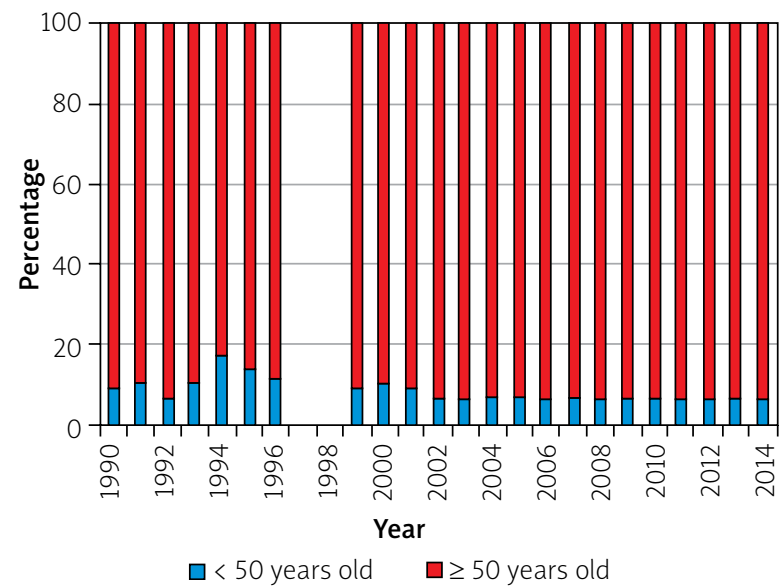

C

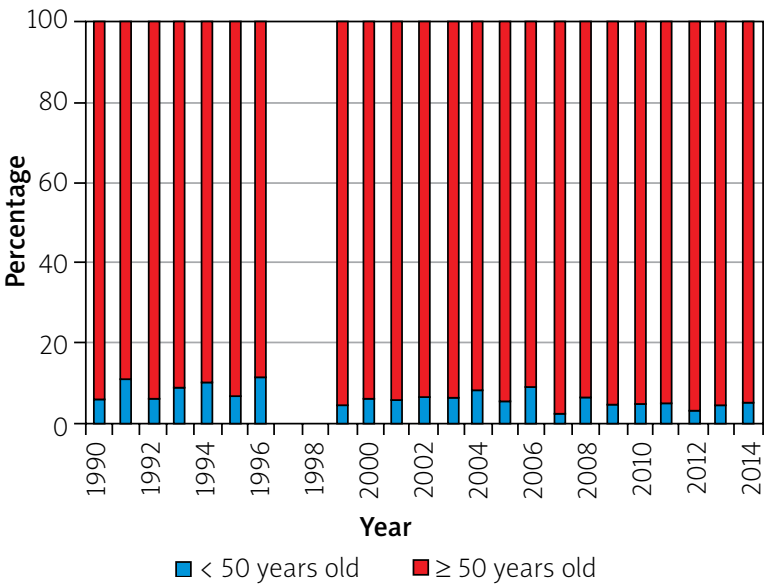

B

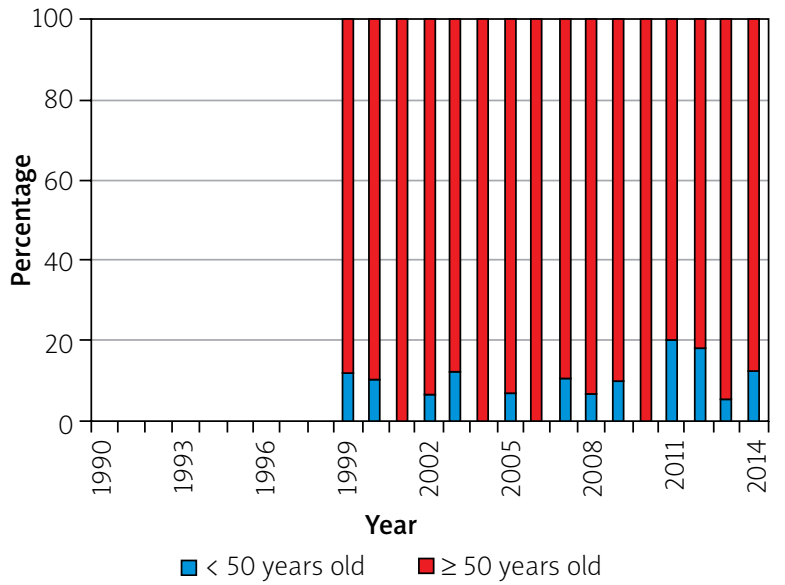

D

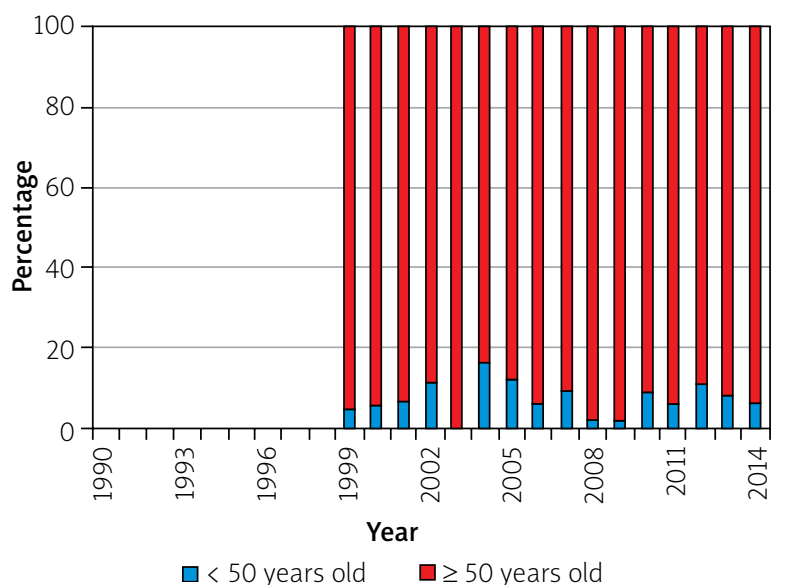

Figure 5. Disease incidence: distribution by C18-C21 codes between 1990 and 2014 in the Podkarpackie region by age: $\mathbf{A}-\mathrm{C} 18, \mathbf{B}-\mathrm{C} 19, \mathbf{C}-\mathrm{C} 20, \mathbf{D}-\mathrm{C} 21$

In the same ratio (more than 12 times for men and more than 8 times for women) the number of cases identified in Poland also increased (men 797 vs. 9964, women 970 vs. 8082, respectively) [9-11].

The problem, according to Polish and foreign literature, concerns not only Poland, because global colorectal cancer rates have increased by up to 10 times, with growing disparities between countries [12, 13, 46-48].

In our study we have confirmed that colorectal cancer presents higher occurrence in men than in women, which was also observed by other authors [49-52].

In view of the fact that around $2 / 3$ of all colorectal cancer cases occur in highly developed countries, it is important to note that in recent years there has been a stabilisation and even a lowering of the growth trend (Western Europe, US), with still rapidly rising rates in low- and middle-income countries [47, 52]. These tendencies are systematized by the literature identifying 3 groups of countries characterised with different incidence and mortality. Group 1 includes countries in which in the last decade an increase in both incidence and mortality has been recorded. This group is represented by Lithuania, Estonia, Bulgaria, Poland, Latvia, Spain, and Croatia. Group 2 includes countries with an increase in incidence and decrease in mortality, such as Canada, Denmark, Finland, Ireland, Italy, Slovakia, Norway, and Sweden. Group 3 is characterised by a decrease in morbidity and mortality, which is observed in the USA, Australia, New Zealand, Japan, Austria, the Czech Republic, France, and Iceland [50]. In countries with high and very high HDI scores, positive trends in incidence and mortality are associated with the implementation of effective, early diagnostics based on population screening programs, as well as the increase of availability of modern diagnostic and treatment technologies. The introduction of screening programs in the initial period may lead to an increase in incidence as a result of identification of undiagnosed CRC cases; however, ultimately, as a result of removal of pre-cancer lesions, it results in a decrease in incidence and mortality $[6,8,47,48,53,54]$. 
A

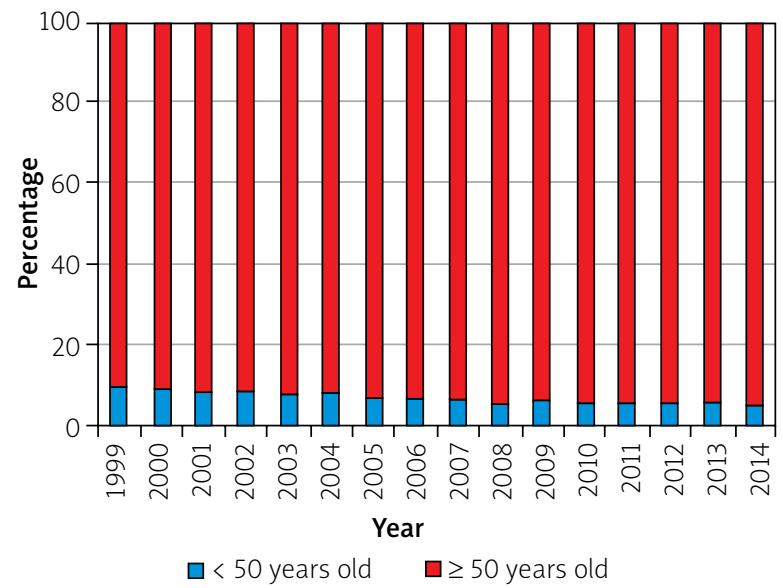

C

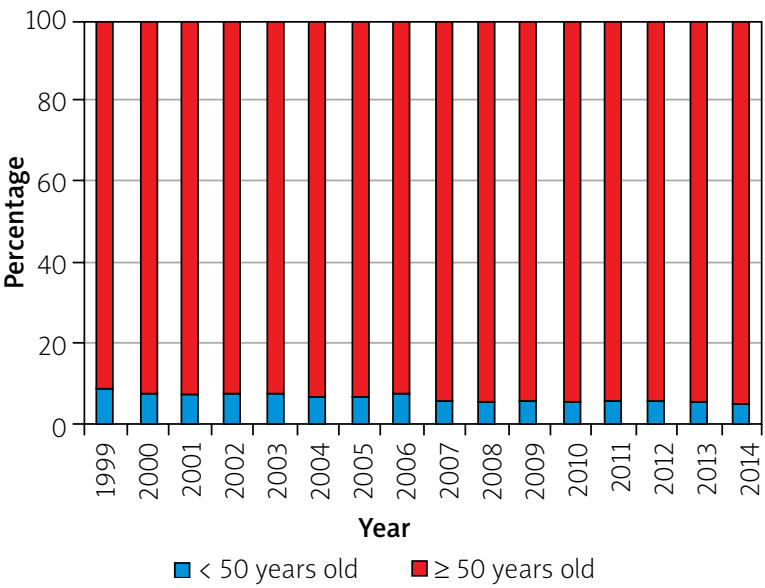

B

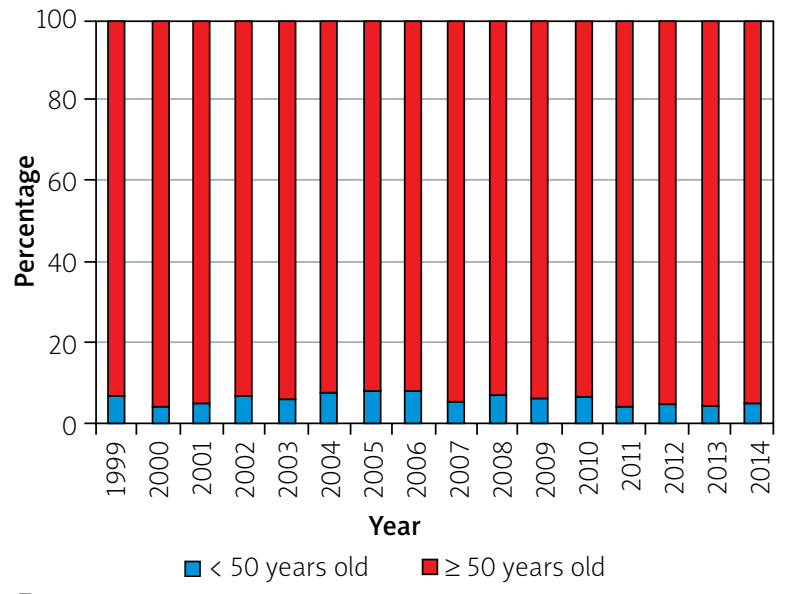

D

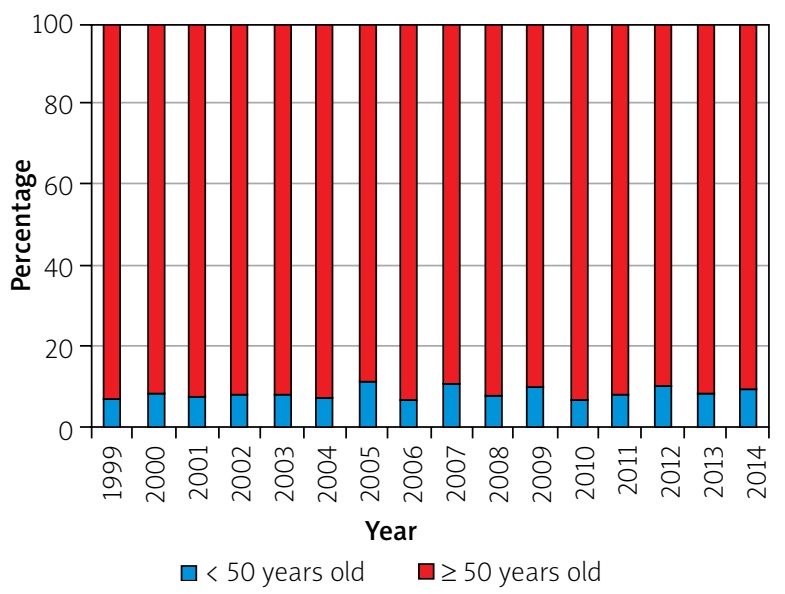

Figure 6. Disease incidence: distribution by $\mathrm{C} 18-\mathrm{C} 21$ codes in the years 1999-2014 in Poland by age: A - C18, B - C19, C - C20, D - C21

The majority of publications emphasize the role of completeness and quality of collected data on incidence and deaths, which are the basis for both assessing the health condition of society, creating epidemiological analyses, and building preventive programs.

Arnold particularly emphasizes in his publications the role of completeness and quality, the sources of obtaining the data used, and the criteria for exclusion from research of countries or registers that do not meet the criteria specified by the WHO $[5,52,55,56]$.

In this aspect, it is impossible not to mention the repeated exclusion in the WHO studies and publications of data on death causality in Poland in 2013 due to exceeding the quality criteria $[4,55]$.

As mentioned at the beginning, the collection and analysis of data of cancer incidence and mortality in Poland faces serious difficulties.

In the field of oncology, the inability to determine the actual cause of death is most often associated with the use of codes C76, 80, and 97 and NOS (not oth- erwise specified). Arnold, following the WHO, defines these codes as "garbage codes".

In 2000 , due to exceeding $25 \%$ of cases coded with "garbage codes" for the first time, data from Poland did not meet the criteria required for comparative mortality analyses. For comparison, the percentage of such codes in the Czech Republic is 15\%, in Germany $14 \%$, in Slovakia $11 \%$, and in Hungary $6-7 \%$. However, among the "garbage codes" those related to cardiovascular diseases dominate. In 2014 such oncological "garbage codes" were used in 4024 cases in Poland $[4,57]$.

In 2013, 29.5\% of death records were improperly coded, i.e. they could not determine the actual cause of death [58]. In turn, the development of oncological yearbooks in Podkarpackie faced the problem of the lack of ICD 9 codes, incorrect or incomplete coding, and the use of "garbage" ICD 10 codes in hospital files, cancer registry reports, and death registries, which in turn prevented proper coding of all cases diagnosed according to the results of postoperative histopathological examinations [59]. 
In Poland, the cancer incidence in male patients in the early 2000s was characterised by rapid growth. The average crude incidence rate for men in the 1960s was 6.8 per 100,000 inhabitants, whereas for the Podkarpackie region it was 5.5 .

In each of the subsequent decades, both in Poland and in the Podkarpackie region, this rate was steadily increasing, reaching in the second decade of the $21^{\text {st }}$ century the values of 49.9 and 47.1 , respectively.

From the 1960s to the 1990s, the average annual increase rate in the Podkarpackie region grew in each decade (from $0.6 \%$ to $5.7 \%$ ). This process slowed down in the early 2000s. This resulted in a decrease in the rate of increase in the first decade to $5.1 \%$, and in the following decade to $4.6 \%$. In Poland, the largest average annual rate of increase in the male incidence rate was observed in the 1960s (8.5\%), while in the following decades it remained close to the regional level.

In the Polish female population, the rapid increase in colorectal cancer incidence continued until the middle of the 1990s, and since then the rate of increase has decreased [7, 14, 46].

Among women, the average value of the crude incidence rate at the beginning of the analysed period was 7.3 per 100,000 inhabitants in Poland, while in the Podkarpackie region it was 6.7. In both cases it was higher than among men. This dependence continued over the next 2 decades. In the 1990s the trend reversed - the rates for men started to exceed the rates for women, and this trend continued until the end of the observation period.

It is worth pointing out that from the 1960s to the 1990s, the average annual rate of increase for women in the 2 areas concerned was characterised by a similar pattern of volatility. Starting from a high level (above $7 \%$ in the first decade) it declined significantly over the next 3 periods. The start of the $21^{\text {st }}$ century, with the continuing national pace, brought about a significant increase in the average annual incidence rate for women in the Podkarpackie region [9, 11, 15-43]. Referring to the changes that took place in the European countries included in groups 2 and 3, it is worth emphasizing that the decrease in the incidence and mortality in relation to women signalled for the Czech Republic has been visible since 2003, while in Sweden and Norway, where the rates were similar to those in Poland, a significant improvement has only been visible in recent years $[45,60]$.

The majority (more than 90\%) of colorectal cancers occur after 50 years of age, with more than $75 \%$ of cases in people over 60 years of age $[44,46]$.

According to Hagagar, colorectal cancer occurrence in people aged 60-79 years is 50 times higher than in young patients (under the age of 40 years). However, disease occurrence in young people is observed more and more frequently. In the USA, colorectal cancer is one of the 10 most commonly identified cancers among 20-49-year-olds [13, 50]. Similar observations are signalled by Gutlic in the Swedish population, with an increase of $27-52 \%$ per decade for colon cancer observed in the age group below 50 years, both in men and women, while in cancer of the rectum it increased in men below 50 years of age, it decreased in both sexes $80+$ years old, and remained unchanged in other age groups $[60,61]$. In turn, Park in his material of 226,352 cases has shown the percentage of patients under 39 years of age to be around 5\% [51].

In the Podkarpackie region, the average age of cancer incidence of both women and men showed a moderate upward trend in the last years, being estimated at a level of around 68 years. Over 5 decades of observation, the average age of disease incidence increased from 64.5 to 68.4 in women and from 64.0 to 67.6 years in men.

An analysis of the disease incidence in patients under and above 50 years of age showed (in particular for the 2 main cancers: colon cancer and rectum cancer) that less than $8 \%$ of cases occurred in patients under 50 years of age, with a parallel increase in the number of cases was seen in patients over the age of 50 years. This trend follows the pattern observed in the general population. In neighbouring countries the following was observed, in the Czech Republic in 1999-2014 patients with colorectum cancer under 50 years old constituted $5.25 \%$, in Ukraine in 2002-2012 this figure was 8\%, and in Slovakia in 2000-2010 it was 7.4\% [45, 62]. It seems that despite including these countries in 3 different categories in the incidence and mortality rate of colorectal cancers, the impact of economic, social, and lifestyle factors on incidence and mortality trends in this region should also be associated with socio-political transition, particularly in countries of the former Eastern Bloc.

\section{Conclusions}

In 1963-2014, the incidence of colorectal cancer in the Podkarpackie region was lower than the average incidence in Poland. Between 1963 and 2014, the number of cases of colorectal cancer identified in the region increased 8.1-fold in men and 12.7-fold in women. In the Podkarpackie region, similarly to the remaining part of Poland, the average value of the crude female incidence rate during the first 2 decades of the period considered was higher than that of men. This trend reversed in the 1990s. Between 1963 and 1999, the average annual rate of increase in the Podkarpackie region increased between $0.6 \%$ and $5.7 \%$ in each decade, with a slight slowdown in the early 2000 s. In the region stud- 
ied, the average rate of increase in the female incidence rate fell significantly until the end of the $20^{\text {th }}$ century, then grew significantly at the start of the $21^{\text {st }}$ century, in contrast to the national pace. Over the course of 50 years, the average age at colorectal cancer diagnosis has increased by 3.9 years for women and by 3.6 years for men.

\section{Conflict of interest}

The authors declare no conflict of interest.

\section{References}

1. World Cancer Research Fund International American Institute for Cancer Research. Continous Update Project Report Diet: Diet, Nutrition Physical Activity and Colorectal Cancer, (2017); https://www.wcrf.org/sites/default/files/Colorectal-Cancer-2017-Report.pdf (access: 23 February 2019).

2. Forman D, Bray F, Brewster DH, et al. Cancer Incidence in Fire Continents, vol. X. IARC Scientific Publiction 2014; 10: 164.

3. Brenner H, Kloor M, Pox CP. Colorectal cancer. Lancet 2014; 383: 1490-502.

4. Cierniak-Piotrowska M, Marciniak G, Stanczak J. Statystyka zgonów i umieralności z powodu chorób układu krążenia" In Rządowa Rada Ludnościowa. „Zachorowalność i umieralność na choroby układu krążenia a sytuacja demograficzna Polski”, Warszawa 2015.

5. Araghi M, Soerjomataram I, Jenkins M, et al. Global trends in colorectal cancer mortality: projections to the year 2035. Int J Cancer 2019; 144: 2992-3000.

6. Reguła J, Rupinski M, Kraszewska E, et al. Colonoscopy in colorectal cancer screening for detection of advanced neoplasia. N Engl J Med 2006; 355: 1863-72.

7. Zatoński WA, Sulkowska U, Didkowska J. Kilka uwag o epidemiologii nowotworów w Polsce. Nowotwory J Oncol 2015; 65: 179-96.

8. Kamiński MF, Reguła J, Kraszewska E, et al. Quality indicators for colonoscopy and the risk of interval cancer. N Engl J Med 2010; 362: 1795-803.

9. Wojciechowska U, Olasek P, Czauderna K, et al. Cancer in Poland in 2014. Oncology Centre - Maria Skłodowska-Curie Institute, National Cancer Register, Department of Epidemiology and Prevention of Cancer, Warsaw 2016.

10. Own research - the archives of the former Rzeszowski Register of Oncology - not published.

11. Koszarowski T, Gadomska H, Wronkowski Z. Cancer in Poland in 1952-1982. Warsaw Centre of Oncology - Institute, Warsaw 1985.

12. Arnold M, Sierra MS, Laversanne M, et al. Global patterns and trends in colorectal cancer incidence and mortality. Gut 2017; 66: 683-91.

13. Hagger F, Boushey RP. Colorectal cancer epidemiology, incidena, mortality, survival and risk factor. Clin Colon Rectal Surg 2009; 22: 191-7.

14. Kubiak A, Kycler W, Trojanowski M. Epidemiology and prevention of colorectal cancer in Poland. Probl Hig Epidemiol 2014; 95: 636-42.
15. Ciąpała T. Nowotwory złośliwe w województwie podkarpackim w latach 1999-2005, Podkarpackie Centre of Public Health, Rzeszów 2007.

16. Zatoński W, Tarkowski W, Chmielarczyk W. Cancer in Poland in 1984. Oncology Centre - Maria Skłodowska-Curie Institute, Warsaw 1987.

17. Zatoński W, Tarkowski W, Chmielarczyk W. Cancer in Poland in 1985. Oncology Centre - Maria Skłodowska-Curie Institute, Warsaw 1988.

18. Zatoński W, Tarkowski W, Chmielarczyk W. Cancer in Poland in 1986. Oncology Centre - Maria Skłodowska-Curie Institute, Warsaw 1989.

19. Zatoński W, Tarkowski W, Chmielarczyk W. Cancer in Poland in 1987. Oncology Centre - Maria Skłodowska-Curie Institute, Warsaw 1990.

20. Zatoński W, Tarkowski W, Chmielarczyk W. Cancer in Poland in 1988. Oncology Centre - Maria Skłodowska-Curie Institute, Warsaw 1991.

21. Zatoński W, Tarkowski W, Chmielarczyk W. Cancer in Poland in 1989. Oncology Centre - Maria Skłodowska-Curie Institute, Warsaw 1992.

22. Zatoński W, Tarkowski W. Cancer in Poland in 1990. Oncology Centre - Maria Skłodowska-Curie Institute, Warsaw 1993.

23. Zatoński W, Tarkowski W. Cancer in Poland in 1991. Oncology Centre - Maria Skłodowska-Curie Institute, Warsaw 1994.

24. Zatoński W, Tarkowski W. Cancer in Poland in 1992. Oncology Centre - Maria Skłodowska-Curie Institute, Warsaw 1995.

25. Zatoński W, Tarkowski W. Cancer in Poland in 1993. Centrum Onkologii -Maria Skłodowska-Curie Institute, Warsaw 1996.

26. Zatoński W, Tarkowski W. Cancer in Poland in 1994. Centrum Onkologii - Maria Skłodowska-Curie Institute, Warsaw 1997.

27. Zatoński W, Tarkowski W. Cancer in Poland in 1995. Oncology Centre - Maria Skłodowska-Curie Institute, Warsaw 1998.

28. Zatoński W, Tarkowski W. Cancer in Poland in 1996. Oncology Centre - Maria Skłodowska-Curie Institute, Warsaw 1999.

29. Wojciechowska U, Didkowska J, Tarkowski W. Cancer in Poland in 1999. Oncology Centre - Maria Skłodowska-Curie Institute, Warsaw 2001.

30. Wojciechowska U, Didkowska J, Tarkowski W. Cancer in Poland in 2000. Centrum Onkologii - Maria Skłodowska-Curie Institute, Warsaw 2002.

31. Wojciechowska U, Didkowska J, Tarkowski W. Cancer in Poland in 2001. Oncology Centre - Maria Skłodowska-Curie Institute, Warsaw 2003.

32. Wojciechowska U, Didkowska J, Tarkowski W. Cancer in Poland in 2002. Oncology Centre - Maria Skłodowska-Curie Institute, Warsaw 2004.

33. Wojciechowska U, Didkowska J, Tarkowski W. Cancer in Poland in 2003. Oncology Centre - Maria Skłodowska-Curie Institute, Warsaw 2005.

34. Wojciechowska U, Didkowska J, Tarkowski W. Cancer in Poland in 2004. Oncology Centre - Maria Skłodowska-Curie Institute, Warsaw 2006.

35. Wojciechowska U. Cancer in Poland in 2005. Oncology Centre - Maria Skłodowska-Curie Institute, Warsaw 2007.

36. Wojciechowska U. Cancer in Poland in 2006. Oncology Centre - Maria Skłodowska-Curie Institute, Warsaw 2008. 
37. Wojciechowska U, Didkowska J, Zatoński W. Cancer in Poland in 2007. Oncology Centre - Maria Skłodowska-Curie Institute, Warsaw 2009.

38. Wojciechowska U, Didkowska J, Zatoński W. Cancer in Poland in 2008. Oncology Centre - Maria Skłodowska-Curie Institute, Warsaw 2010.

39. Wojciechowska U, Didkowska J, Zatoński W. Cancer in Poland in 2009. Oncology Centre - Maria Skłodowska-Curie Institute, Warsaw 2011.

40. Wojciechowska U, Didkowska J, Zatoński W. Cancer in Poland in 2010. Oncology Centre -Maria Skłodowska-Curie Institute, Warsaw 2012.

41. Didkowska J, Wojciechowska U, Zatoński W. Cancer in Poland in 2011. Oncology Centre - Maria Skłodowska-Curie Institute, Warsaw 2013.

42. Wojciechowska U, Didkowska J, Zatoński W. Cancer in Poland in 2012. Oncology Centre - Maria Skłodowska-Curie Institute, Warsaw 2014.

43. Didkowska J, Wojciechowska U. Cancer in Poland 2013. Oncology Centre - Maria Skłodowska-Curie Institute. National Cancer Register, Department of Epidemiology, Warsaw 2015.

44. Zyśk R, Wysocki P, Wyrwicz L, Colorectal cancer - the social significance of changes in the epidemiology and treatment options in Poland. Onkol Prakt Klin 2014; 10: 212-23.

45. Epidemiology of Malignant Tumores in the Czech Republic http://www.svod.cz (access May 01. 2020).

46. Rafiemanesh H, Pakzad R, Abedi M, et al. Colorectal cancer in Iran: epidemiology and morphology trends. EXCLI J 2016; 15: 738-44.

47. Favoriti P, Carbone G, Greco M, et al. Worldwide burden of colorectal cancer: a review. Updates Surg 2016; 68: 7-11.

48. Dekker E, Tanis PJ, Vleugels J, et al. Colorectal cancer. Lancet Seminar 2019; 394: 1467-80.

49. Murphy G, Devesa SS, Cross AJ, et al. Sex disparities in colorectal cancer incidence by anatomie subsite, race and age. Int J Cancer 2011; 128: 1668-75.

50. Rawla P, Sunkara T, Barsouk A. Epidemiology of colorectal cancer: incidence, mortality, survival, and risk factors. Gastroenterology Rev 2019; 14: 89-103.

51. Hyoung-Chul P, Aesun S, Byung-Woo K, et al. Data on the characteristics and the survival of Korean patients with colorectal cancer from the Korea Central Cancer Registry. Coloproctology 2013; 92904: 144-9.

52. Gunter MJ, Alhomoud S, Arnold M, et al. Meeting report from the joint IARC-NCI International cancer seminar series: a focus on colorectal cancer. Ann Oncol 2019; 30: 510-9.

53. Essink-Bot ML, Dekker E. Eqal acces to colorectal cancer screening. Lancet 2016; 387: 724-6.

54. Navarro M, Nicolas A, Ferrandez A, Lanas A. Colorectal cancer population screening programs worldwide in 2016: an update. World J Gastroenterol 2017; 23: 3632-42.

55. Mathers CD, Fat DM, Inoue M, et al. Counting the dead and what they died from: an assessment of the global status of cause of death data. Bull World Health Organ 2005; 83: 171-7.

56. Arnold M, Rutherford MJ, Bardot A, et al. Progress in cancer survival, mortality, and incidence in seven high-income countries 1995-2014 (ICBP SURVMARK-2): a population-based study. Lancet Oncol 2019; 20: 1493-505.
57. Statistics Poland https://stat.gov.pl/obszary-tematyczne/ludnosc/statystyka-przyczyn-zgonow (access May 01. 2020).

58. Cierniak-Piotrowska M, Marciniak G, Stanczak J. Statystyka zgonów i umieralności z powodu chorób układu krążenia. In: Rządowa Rada Ludnościowa. „Zachorowalność i umieralność na choroby układu krążenia a sytuacja demograficzna Polski”, Warsaw 2015.

59. Grądalska-Lampart M, Patro A, Radziszewska A, Gawełko J. Nowotwory złośliwe w województwie podkarpackim w 2010 roku http://www.szpital.rzeszow.pl/gfx/szpital/files/nowotwory_zlosliwe_w_wojewodztwie_podkarpackim_w_2010_roku. pdf. (access May 01. 2020).

60. Cancer statistics for the Nordic countries. https://www-dep. iarc.fr/NORDCAN/english/frame.asp (access May 01. 2020).

61. Gutlic I, Schyman T, Lydrup ML, et al. Increasing colorectal cancer incidence in individuals aged $<50$ years - a population-based study. Int J Colorect Dis 2019; 34: 1221-6.

62. ECIS - European Cancer Information System From https://ecis. jrc.ec.europa.eu (accessed April 25 2020).

Received: 18.10 .2019

Accepted: 15.05 .2020 